\title{
Earthquakes-Rattling the Earth's Plumbing System
}

Hydrogeologic responses to earthquakes have been known for decades, and have occurred both close to, and thousands of miles from earthquake epicenters. Water wells have become turbid, dry or begun flowing, discharge of springs and ground water to streams has increased and new springs have formed, and well and surfacewater quality have become degraded as a result of earthquakes. Earthquakes affect our Earth's intricate plumbing system — whether you live near the notoriously active San Andreas Fault in California, or far from active faults in Florida, an earthquake near or far can affect you and the water resources you depend on.

\section{Responses in water wells}

Water-level fluctuations caused by the 1964 magnitude(M) 8.5 Alaska earthquake were recorded in 716 wells in the United States (Vorhis, 1966); the earthquake also was registered on water-level recorders in many other countries. Responses of water levels in wells to earthquakes are influenced by such factors as the magnitude and depth of the earthquake, distance from the epicenter, and the hydrogeologic environment, which may be consolidated rock, unconsolidated sediment, karst, or hydrothermally altered. The depth of the well, whether the aquifer is confined or unconfined, and well construction also influence the degree of water-level fluctuations in wells in response to seismic waves. Some aquifers may act as resonators, which may amplify the response.

The most common type of observed ground-water response is an instantaneous water-level offset, or step, which may be either an increase or a decrease and may occur near or far from the epicenter. Recovery to the pre-earthquake water level can be so rapid that no change will be detected if the water level is measured infrequently, or it may take as long as days or months. Steps can be large enough to make a well flow at land surface, or render it dry. The 1998 M5.2 Pymatuning earthquake in northwestern Pennsylvania caused about 120 local household-supply wells to go dry within 3 months after the earthquake (Fleeger and others, 1999). The 2002 M7.9 Denali Fault earthquake in Alaska caused a 2-foot waterlevel rise in a well in Wisconsin, more than a thousand miles from the epicenter.

The other type of ground-water response is a water-level oscillation, which occurs more often, but is less commonly recorded. In the few cases where oscillations have been recorded, they resemble long-period seismograms, known as hydroseismograms. A well in Grants Pass, Oregon, is instrumented to record water levels at 1 -second intervals, and the record from the Denali Fault earthquake shows peak-topeak seismic oscillations of more than 4 feet and a permanent offset of 0.4 feet.

\section{Responses in streams, springs, seeps, and lakes}

Surface-water responses to earthquakes include changes in chemistry, seiches (wave oscillations) in lakes and other open water bodies, increases in stream, spring, and seep discharge, some instances of springs going dry or the appearance of new springs, and a very few examples of decreases in stream discharge. After the Denali Fault earthquake, many eyewitnesses throughout the contiguous United States reported water "sloshing" back and forth in lakes, bayous, ponds, and pools. Seiches lasted as long as half an hour, resulting in broken moorings in Lake Pontchartrain, Louisiana (Seth Moran, U.S. Geological Survey, written commun., 2002).

Well 8N/10W-101 in the western Mojave Desert, California responded to several southern California earthquakes.

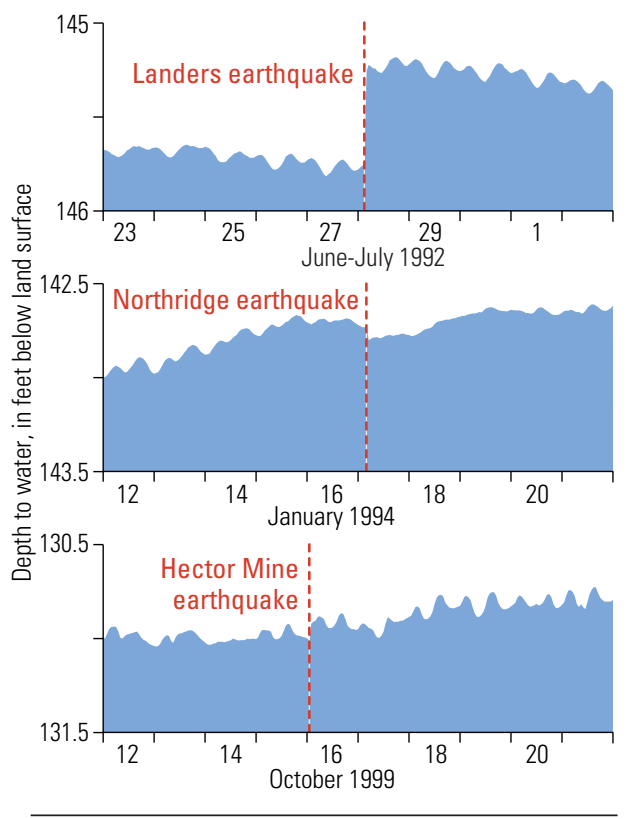

Well M0-18/02W/29-0017 in Wisconsin responded to the distant Denali Fault earthquake in Alaska.

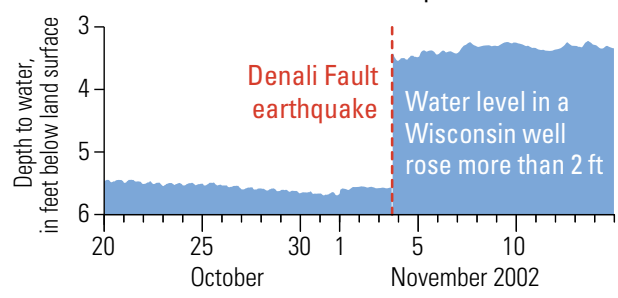




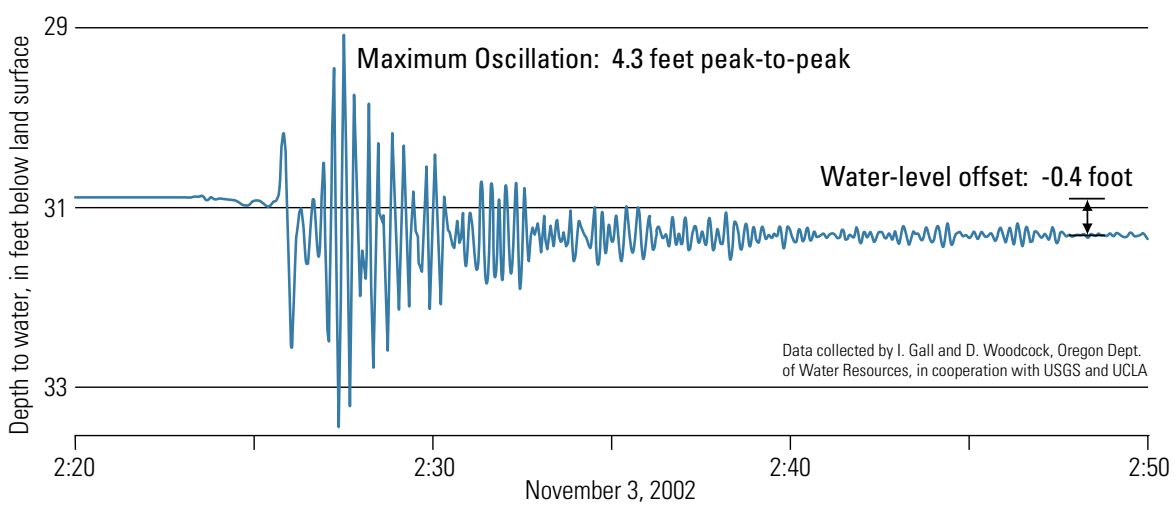

Hydroseismogram recorded in a well near Grants Pass, Oregon, shows water-level oscillations and a small offset relative to pre-earthquake water level in response to the Denali Fault earthquake.

Streamflow may continue to increase for a few days and then gradually decline toward the pre-earthquake baseline condition for several months. Water flowing in a stream can come from overland flow or from ground water discharging into the streambed (baseflow). An abrupt increase in streamflow without precipitation or upstream reservoir release indicates increased contributions from the ground-water system. A coseismic (at the time the seismic wave train arrives) discharge increase of approximately 40 percent was recorded in Santa Paula Creek, California, 35 miles WNW., of the 1994 M6.7 Northridge, California earthquake epicenter (Quilty and others, 1995), and increased discharges were measured at numerous sites in the California Coast Range in response to the 1989 M7.1 Loma Prieta, California earthquake (Rojstaczer and Wolf, 1992). The appearance of new seeps and springs and turbidity in streams also are common. Following the Northridge earthquake, a new oil seep began flowing in the Northern Ojai Valley (Stephen P. Mulqueen, Department of Conservation, Division of Oil, Gas, and Geothermal Resources, oral commun., 2003).

\section{Precursory responses}

Many preseismic or precursory hydrogeologic responses have been reported, but in most cases, documentation has not been sufficient to convince the scientific community of their predictive value or to rule out explanations unrelated to earthquakes. Some investigators believe earthquakes cannot be predicted (Geller and others, 1997), whereas others believe that while earthquake prediction is difficult because of the youthfulness of seismic research and the limited number of case studies to investigate, prediction will not forever be impossible (Wyss, 2001). Roeloffs (1996) states "The documentation of a few of these reports [of precursory hydrogeologic changes] is now approaching levels that require them to be given scientific credibility." Water levels and chemical data seem to be the best documented precursory signals to date, and are monitored in several countries as potential indicators of an impending earthquake.

Japan has some of the best documented occurrences of precursory hydrogeological changes, preceding both the 1978 M6.8 Izu-Oshima earthquake (Oki and Hiraga, 1979; 1987), and the more recent, disastrous 1995 M7.2 Kobe earthquake
(Tsunogai and Wakita, 1995). Before either or both of these events, water-level changes occurred in many wells, and there appeared to have been precursory changes in ground-water temperature, radon, chloride, and sulfate concentrations, as well as dissolved gas ratios in mineral springs (Igarashi and others, 1995; Sugisaki and others, 1996). The preseismic changes in chloride and sulfate content of the Kobe event were reconstructed by analyzing dated, bottled ground water that is distributed in the domestic market. The well-documented and similar hydrogeologic precursors at Izu-Oshima and Kobe have motivated the Japanese government to continue water-level monitoring at more than 30 wells in seismically active areas (Tsukuda and others, 2000). The suggestion of precursory hydrogeologic changes is tantalizing, because the ultimate goal of most earthquake research is to reduce the hazard posed by major events, and providing some warning of impending activity would be very useful in that regard.

\section{Hazards related to hydrogeologic responses}

Hydrogeologic responses to earthquakes can create a variety of hazards. Water supply may be disrupted if wells go dry or become too turbid to pump, and infrastructure damage may result from ground motion. After the 1992 M7.3 Landers,
This pristine spring in the unique environment of Ash Meadows in Nevada is hydrologically connected to Devil's Hole, which is a nearly vertical cavern below the water table in southern Nevada. An endangered species, Devil's Hole pupfish, has lived in Devil's Hole pool for thousands of years. The water level in Devil's Hole oscillated in response to the Denali Fault earthquake, which disrupted the spawning areas of the pupfish near the surface of the pool.
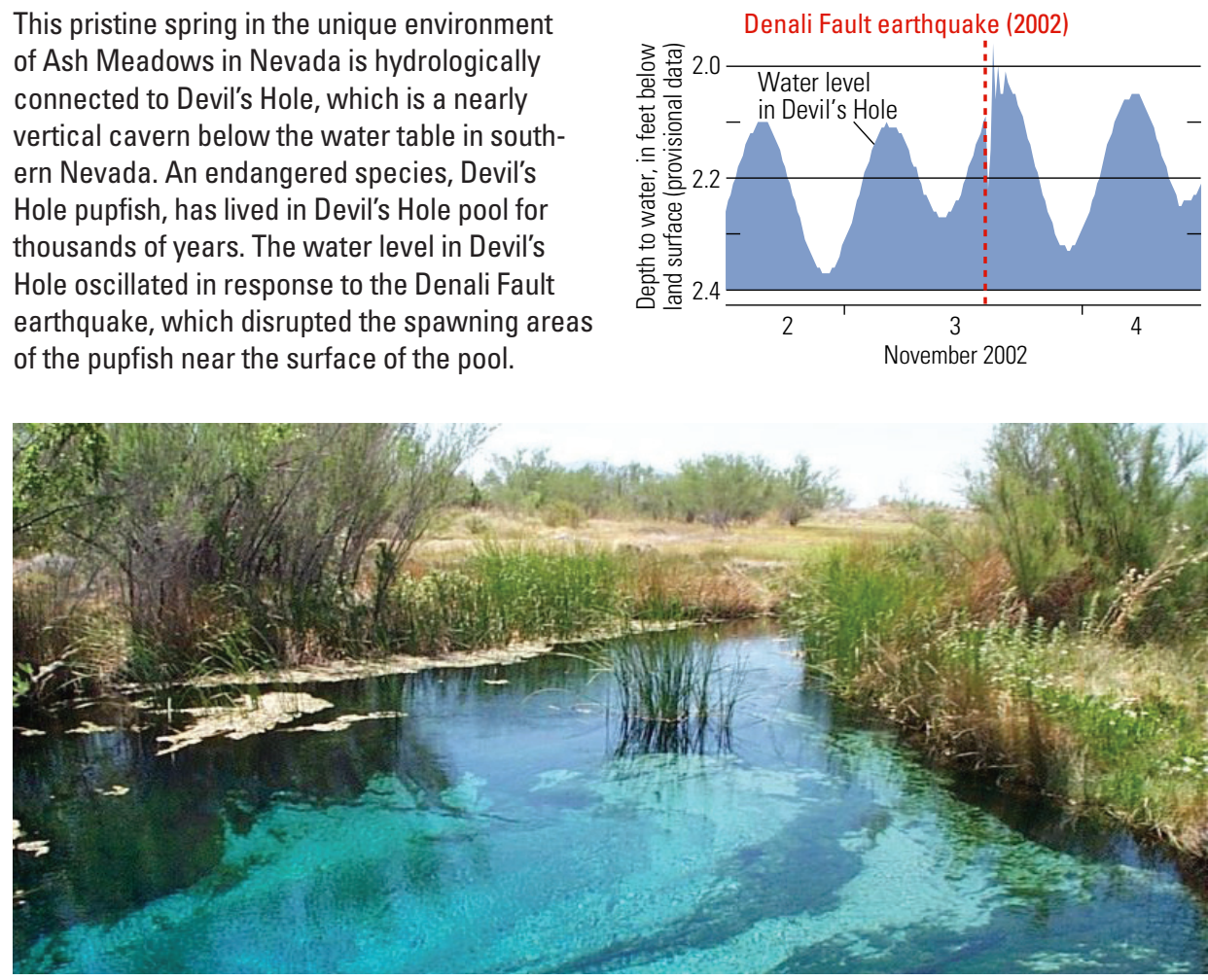


\section{Mechanisms for Hydrogeologic Responses to Earthquakes}

Known hydrogeologic responses most often occur as the seismic wave train arrives (coseismic) or sometime thereafter (postseismic); evidence of precursory (preseismic) hydrogeologic changes is becoming more compelling, but additional scientific investigation is needed to explain these phenomena.

Water levels in wells respond to the seismic-wave induced expansion and contraction of the aquifer tapped by the well, in turn causing step or oscillatory fluid-pressure changes. If flow in the wellaquifer system is fast enough, then these pressure changes cause flow into and out of the well, which sets up resonant motion of the water column, and the result is the seldom-recorded water-level oscillation. The more commonly recorded water-level offsets have been measured both near and far from earthquake epicenters. Offsets are expected in the 'near field', or static strain field, of an earthquake because the earthquake subjects the earth's crust, including its aquifer systems, to stress and permanent strain (deformation). This deformation process results in altered fluid pressure within the aquifer systems, and consequently, a steplike change in water level would be expected (Quilty and others, 1995; Roeloffs and others, 1995). The earthquake-induced water-level decline in well 9N/10W-36J1 is the expected response for an extensionally strained region (Roeloffs and others, 1995). Providing that the water-level response to strain is known, this relation allows scientists to use the earthquake response of water levels in favorably located and designed wells to measure strain, and also to calculate otherwise difficult-to-measure hydrologic properties of the aquifer. At distances of hundreds or thousands of miles, the offset can often be directly related to the amount
Santa Paula spring: Increased discharge

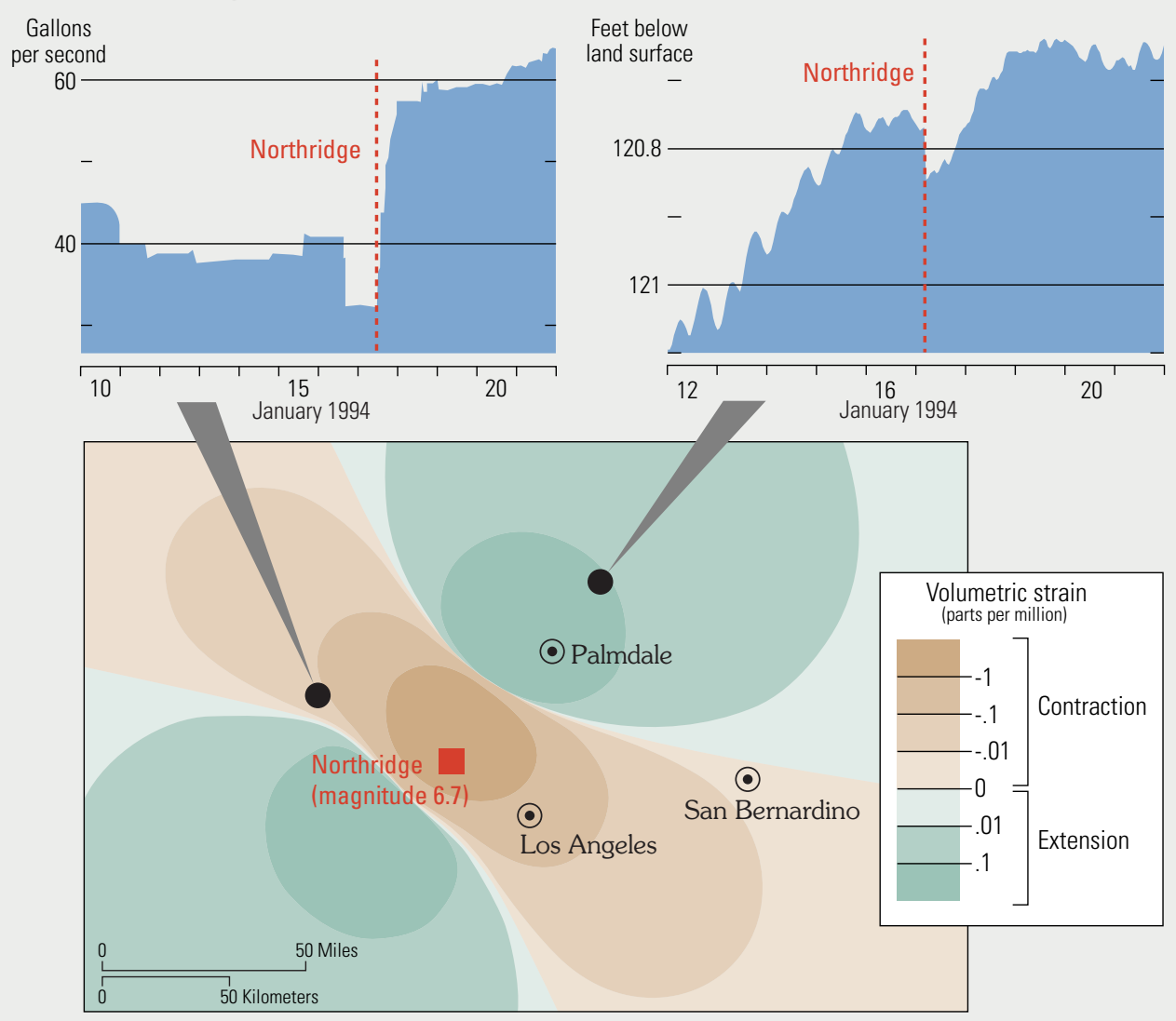

of deformation produced by movement on the earthquake fault (Roeloffs, 1988).

Possible mechanisms for responses are variable. For upward steps in shallow wells, compaction of overlying alluvium such as occurs during liquefaction may be the mechanism producing the offset (Roeloffs, 1998). Fluid-pressure declines also can be caused by the escape of small amounts of exsolved gas from pore spaces in response to seismic waves. In a fractured rock environment such as northwestern Pennsylvania where the Pymatuning earthquake occurred, permeability may be altered due to the unclogging, widening, or narrowing of a fracture, or the creation of new fractures (Fleeger and others, 1999). Similarly, an increase in co- and postseismic ground-water discharge at the surface through a spring, seep, or stream, can be caused by an increase in vent or fracture conductance (Muir-Wood and King, 1993), or an increase in the subsurface fluid pressure or permeability in the formation (Rojstaczer and Wolf, 1992; Roeloffs and others, 1995). The earthquake-induced increased discharge in Santa Paula spring is the expected response for a contractionally strained region (Roeloffs and othand discussion of potential mechanisms see Montgomery and Manga (2003). ers, 1995). For a brief review of streamflow and water well responses to earthquakes
California earthquake, bubbles of gas (carbon dioxide-enriched air) appeared in water from several San Bernardino, California, supply wells, clogging and disabling the filtration system (Roeloffs and others, 1995). Hydrogeologic responses that cause wells to flow or streamflow to increase may cause flooding, landslides, erosion, and other related problems. Water quality also may be adversely affected by increased discharge, turbidity, or hydrogeochemical changes. Following the Landers earthquake, a pre-existing oil and natural gas seep in Tapo Canyon became more active, eventually flowing into and polluting the Santa Clara River (Roeloffs and others, 1995).

Water-quantity and quality changes following an earthquake can adversely affect sensitive ecosystems, harming the plants and animals that live there. The endangered Devil's Hole pupfish (Cyprinodon diabolis) has lived for thousands of years in only one pool in Ash Meadows, Nevada, spawning on a single $6 \times 13$ foot shelf just below the water surface. In 1978, an earthquake in Mexico caused such violent water-level oscillations in Devil's Hole that algae was scoured from 
the shallow shelf (Death-Valley.us, http: //www.death-valley.us/article107.html, accessed January 29, 2003), and the 2002 Denali Fault earthquake also apparently caused oscillations of 5-6 feet (Jim Roche, National Park Service, written commun., 2002). A persistent drop of water level below the shelf could extinguish the pupfish, whose life span is only a few years. Although court orders and careful management have led to population stability, the existence of the Devil's Hole pupfish remains precarious.

Ground-water systems are mechanically coupled to the rocks and sediments in which they exist. In addition to hydrogeologic responses to earthquakes, hydrogeologic changes may cause earthquakes or volcanic events. Earthquakes can be induced by the filling of surface reservoirs, or by annual or shorter-term fluctuations in reservoir levels, as is the case in most shallow earthquakes in the Aswan, Egypt area (Awad and Mizoue, 1995). Earthquakes also can be induced by the injection or withdrawal of fluids through wells, as was illustrated by the earthquakes caused by injection of waste fluid from munitions production at the Rocky Mountain Arsenal in the 1960s (Healy and others, 1968). More speculatively, the observation that large earthquakes can cause distant hydrogeologic changes may help explain how the

\section{Recording Accurate Hydrogeologic Responses}

Measurement techniques often do not adequately reflect hydrogeologic responses to earthquakes. In the recent past, water levels and discharge were recorded continuously using a drum recorder, similar to the method in which earthquakes are recorded on a seismograph. More recently, scientists have migrated to more cost-effective digital measurements that are recorded on an electronic datalogger. Ground-water levels typically change slowly, and dataloggers have limited storage capacity, such that data are recorded at 15-minute intervals, or more often, at 30- or 60 -minute intervals. With a recording interval on this order, a water-level response from an earthquake may not be adequately defined by the periodic data; the recovery to the pre-earthquake water level can occur so quickly that no change will be detected. In some cases, the water-level response is not in the expected direction because the initial response was not recorded, or because the response is affected by the particular well construction (the well-bore storage effect). Although stream or spring discharge may change as a result of a change in the ground-water contribution to the baseflow of the stream, surface-water discharge measurements often are not accurate enough to reliably detect small changes in flow. Additionally, flow is often controlled artificially, either partially or completely, preventing the detection of earthquake-induced changes.

1992 M7.3 Landers, California earthquake triggered microearthquakes at a number of locations many hundreds of miles from the epicenter (Hill and others, 1993).

\section{Conclusions}

Hydrogeologic responses to large distant earthquakes have important scientific implications with regard to our earth's intricate plumbing system. The exact mechanism linking hydrogeologic changes and earthquakes is not fully understood, but monitoring these changes improves our insights into the responsible mechanisms, and may improve our frustratingly imprecise ability to forecast the timing, magnitude, and impact of earthquakes.

Michelle Sneed, Devin L. Galloway and William L. Cunningham

\section{References}

Awad, M., and Mizoue, M., 1995, Earthquake activity in the Aswan region: Pure and Applied Geophysics, 145, p. 69-86.

Death-Valley.us, Devil's hole pupfish-Cyprinodon diabolis: Death-Valley.us Forums, article 107, posted July 18, 2002, accessed January 29, 2003, at http: //www.death-valley.us/article107.html

Fleeger, Gary M., Goode, D. J., Buckwalter, T.F., and Risser, D.W., 1999, Hydrologic effects of the Pymatuning Earthquake of September 25, 1998, in Northwestern Pennsylvania: U.S. Geological Survey Water-Resources Investigations Report 99-4170, 8 p.

Geller, R.J., Jackson, D.D., Kagan, Y.Y., and Mulargia, F., 1997, Earthquakes cannot be predicted: Science, 275, p. 1616-1617.

Healy, J.H., Rubey, W.W., Griggs, D.T., and Raleigh, C.B., 1968, The Denver earthquakes: Science 161, p. $1,301-1,310$

Hill, D.P., and others, 1993, Seismicity remotely triggered by the magnitude 7.3 Landers, California, earthquake: Science, v. 260, no. 5114, p. 1617-1623.

Igarashi, G., Saeki, S., Takahata, N., Sumikawa, K., Tasaka, S., Sasaki, Y., Takahashi, M., and Sano, Y., 1995, Groundwater radon anomaly before the Kobe earthquake in Japan: Science, 269, p. 60-61.

Montgomery, D.R., and Manga, M., 2003, Streamflow and water well responses to earthquakes: Science, v. 300, p. 2047-2049.

Muir-Wood, R., and King, G.C.P., 1993, Hydrological signatures of earthquake strain: Journal of Geophysical Research, 98, p. 22,035-22,068.

Oki, Y., and Hiraga, S., 1979, Water level anomalies prior to the Izu-Oshima earthquake, January 14, 1978, Translated from the Japanese by E. Silberman, in Technical Report 79-2, Lamar-Merifield Geologists, Special Technical Report for the U.S. Geological Survey. , 1987, Groundwater-level monitoring for prediction of earthquakes: Pure and Applied Geophysics 126.

Quilty, E.G., Farrar, C.D., Galloway, D.L., Hamlin, S.N., Laczniak, R.J., Roeloffs, E.A., Sorey, M.L., and Woodcock, D.E., 1995, Hydrologic effects associated with the January 17, 1994 Northridge, California, earthquake: U.S. Geological Survey Open-File Report 95-813, 47 p.

Roeloffs, E., 1988, Hydrologic precursors to earthquakes: A review: Pure and Applied Geophysics 126, p. 177-209.

Roeloffs, E., 1996, Poroelastic techniques in the study of earthquake-related hydrologic phenomena: Advances in Geophysics, 37, p. 135-195.

Roeloffs, E., 1998, Persistent water level changes in a well near Parkfield, California, due to local and distant earthquakes: Journal of Geophysical Research, v. 103 (B1), p. 869-889.

Roeloffs, E., Danskin, W.R., Farrar, C.D., Galloway, D.L., Hamlin, S.N., Quilty, E.G., Quinn, H.M., Schaefer, D.H., Sorey, M.L., and Woodcock, D.E., 1995, Hydrologic effects associated with the June 28, 1992 Landers,
California, earthquake sequence: U.S. Geological Survey Open-File Report 95-42, 68 p.

Rojstaczer, S., and Wolf, S., 1992, Permeability changes associated with large earthquakes: An example from Loma Prieta, California, 10/17/89: Geology, 20, p. 211-214.

Sugisaki, R., Ito, T., Nagamine, K., and Kawabe, I., 1996, Gas geochemical changes at mineral springs associated with the 1995 southern Hyogo earthquake (M=7.2), Japan: Earth and Planetary Science Letters, 139, p. 239-249.

Tsukuda, E., Koizumi, N., and Yasuto, K., 2000, Integrated groundwater monitoring studies in the intensified observation area and near major active faults, Bulletin of the Geological Survey of Japan, v. 51, no. 9, p. 435-445.

Tsunogai, U., and Wakita, H., 1995, Precursory chemical changes in ground water: Kobe earthquake, Japan: Science, 269, p. 61-63.

Vorhis, Robert C., 1966, Hydrologic effects of the earthquake of March 27, 1964 outside Alaska: U.S. Geological Survey Professional Paper 544-C, 54 p.

Wyss, Max, 2001, Why is earthquake prediction research not progressing faster?: Tectonophysics, 338, p. 217-223.

For Additional Information

U.S. Geological Survey, Information Services Box 25286, Denver Federal Center Denver, CO 80225

Telephone: 1-888-ASK-USGS

World Wide Web: http://www.usgs.gov/ 
